\title{
ANALYSIS OF INSURANCE DOCUMENTS AS AN ALTERNATIVE TOOL FOR TESTING TRANSACTION VALUE IN CUSTOMS VALUE DETERMINATION
}

\author{
Imam Tri Wahyudi \\ Asral Efendi
}

Customs Specialist, Tanjung Priok Customs and Excises Office

Email: imam.tri@customs.go.id

\section{ARTICLE INFORMATION}

Received date

[14-11-2019]

Revision

[23-11-2019]

Accepted date

[09-12-9019]

\begin{abstract}
:
Minister of Finance, Sri Mulyani delivered an update on the realization of the 2019 State Revenue and Expenditure Budget (APBN) as of August 31, 2019. In terms of state revenue, the figure reached $R p$ 1,189.3 trillion. To achieve the revenue target, the Ministry of Finance needs to continuously make efforts to optimize tax revenues. Tanjung Priok Customs Office as part of the Ministry of Finance is required to take strategic steps in optimizing its role as revenue collector, technically regarding customs value determination. One of the challenges in customs value is that importers convey transaction prices below the actual transaction price (under invoicing). This of course also results in a decline in state revenue. Based on these conditions, this study will examine how the analysis of insurance data can be used as an alternative value test tool for import transaction values. This study will capture an overall picture of the insurance document examination process, technical problem and how to make it as an alternative value test tool for import transaction values with a qualitative approach.
\end{abstract}

\section{Keywords: Customs Clearance, Indonesia Customs, Insurance.}

\section{INTRODUCTION}

Minister of Finance Sri Mulyani delivered an update on the realization of the 2019 State Revenue and Expenditure Budget (APBN) as of August 31, 2019. In terms of state revenue,

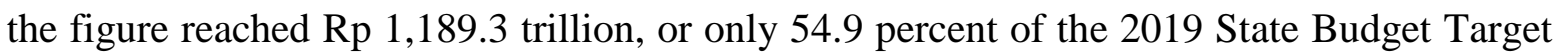
of Rp 2,165.1 percent. The Ministry of Finance (MoF) recorded that tax revenue realization until August 2019 reached Rp 801.02 trillion or 50.78\% of the 2019 APBN target of Rp 
1,577.56 trillion. That number grew $0.21 \%$ compared to the previous year which amounted to Rp799.46 trillion (Ministry of Finance, 2019).

To achieve the revenue target, the Ministry of Finance needs to continuously make efforts to optimize tax revenues without disrupting the business investment climate, tax revenue policies aimed at maintaining national economic stability and maintaining public purchasing power, tax revenue policies aimed at increasing competitiveness and added value national industry, and taxation policies directed at controlling consumption of excisable goods.

In line with the above steps, the Tanjung Priok Customs and Excises Office as part of the Ministry of Finance is required to take strategic steps in optimizing its role as revenue collector. At the technical level, this can be realized by optimizing the import document examination, especially regarding customs value so that it is expected that state revenue can also be optimized.

One of the challenges in customs value is that importers convey transaction prices below the actual transaction price (underinvoicing). Such practice might potentially be resulting in a decline in state revenue. Based on these conditions, this study will examine how the analysis of insurance data can be used as an alternative test tool for import transaction values.

\section{LITERATURE REVIEW AND HYPOTHESIS DEVELOPMENT}

\subsection{Customs Value Definition}

Indonesia adopted the Customs Value provisions based on the 1994 GATT WTO agreement (Agreement on Implementation of Article VII of GATT 1994) and has been stated in laws and minister regulations regarding customs valuation. Customs Value is the transaction value of the relevant imported goods that meet certain conditions that are used as a basis for the calculation of import duties and levies in the framework of other imports. The customs value is the customs value in the International Commercial Terms (incoterms) Cost, Insurance, and Freight (CIF). Customs value is used to calculate import duty if the tariff used is based on advalorum tariff (percentage). The amount size of the import duties levies is highly dependent on the customs value and the tariff imposed on imported goods.

In the self-assessment system, the importer independently notifies the data of imported goods including counting the levies that must be paid. Notification of customs value by importers must be appropriate in accordance with applicable regulations. In the event that customs notification is lower than it should be, in addition to having to pay underpayments, importers are also subject to administrative sanctions in the form of fines.

Referring to the WTO Valuation Agreement, there are 6 (six) methods of determining the customs value that must be applied hierarchically, namely:

- Transaction Value Method,

- Identical Goods Value Method,

- Similar Goods Value Method,

- Deduction Method, 
- Computational Methods,

- Fallback method.

In accordance with the main principles of the WTO Valuation Agreement, the main basis for determining the customs value is the transaction value of the imported goods concerned. Transaction value is the actual price that the buyer is supposed to pay to the seller for goods sold for export into the customs area, plus certain costs, as long as certain costs are not included in the actual price or should be paid. The price actually paid is the price of the goods at the time the goods are imported (submitted import customs notification to the Customs Office) has been paid / paid by the buyer. Whereas the price that is supposed to be paid is the price of the goods at the time of import (the customs declaration is submitted to the Office) has not been paid / paid by the buyer concerned. Costs paid by importers that are not yet included in the price actually paid or that should be paid, in the form of sales commission, packaging cost, assist-royalties-proceeding, transportation and handling cost in the origin country and also insurance costs.

Insurance costs are the costs of guaranteeing the transportation of goods from export locations abroad to import sites in the Customs Area which are generally proven by insurance documents in the form of insurance certificates, insurance policies or open policies. The date of the insurance document must be before or no later than the date of delivery.

\subsection{Customs Value Determination}

In the customs notification model using self-assessment, the importer informs independently of imported goods, including the quantity, type, the transaction value of goods. Furthermore Customs and Excise officials test the transaction values. Transaction value can be accepted if: there are conditions of sale and purchase, and the correctness of the quantity and / or types of goods in the event of a physical inspection. In the event that the transaction value is not fulfilled, the determination of the customs value uses methods II to VI.

If the transaction value requirements are met, officials will compare the fairness of the declared customs value using Customs Value database I (DBNP I). DBNP I is internal database consists of identical goods imported within certain period of time, which is maintained by Customs Office. The value is considered acceptable when the value is within a maximum tolerance 5\% of DBNP I. If such goods is not available in DBNP I, the officials will then uses Customs Value database II (DBNP II). The goods considered reasonable when the goods price of equivalent or higher than the DBNP II.

In the event that the test results show that it is unacceptable, then Customs Value Information (INP) is issued, which is a document request an explanation related to the transaction value. When the importer does not provide an answer to the INP or provides an answer in the form of a Customs Value Declaration (DNP) but does not convince the official, the transaction value is not accepted. Specifically, customs value research refers to Regulation of the Minister of Finance Number 160 / PMK.04 / 2010 concerning Customs Value for Calculation of Import Duties.

\subsection{Insurance of Importation Goods}


So far, the role of insurance of imported goods is only considered as one of the costs that must be added to become the customs value in calculating Import Duty and Tax in the Framework of Import (PDRI). This can be seen in the Minister of Finance Regulation Number: 160 / PMK.04 / 2010 reads:

Article 5 paragraph (1):

- "Transaction value is the price actually paid or should be paid by the buyer to the seller for goods sold for export into the Customs Area plus costs and / or values that must be added to the transaction value as long as costs and / or these values are not included in the price actually paid or should be paid."

Article 5 Item 3 (g):

- $\quad$ "The costs and / or values referred to include insurance.

Article 21:

- $\quad$ "In the event that insurance costs as referred to in Article 5 paragraph (3) letter g are not included in the transaction value and tangible evidence or objective and measurable data regarding the amount of insurance costs is not available, then the amount of insurance costs used in determining customs value as referred to in Article 18 is $0.5 \%$ (zero point five percent) of the Cost and Freight (CFR) value."

However, the authors see that insurance is not just a cost element added in the calculation of customs value, but it can also be used to minimize the practice of under invoicing in the business process of importing goods. We have already seen such practice in the banking industry, the use of insurance as a protector against the risk of loss in every financial service product that is always given priority, such as in the issuance of $\mathrm{L} / \mathrm{C}$, granting loans, mortgages and others. Then DGCE can encourage the use of insurance not only as a supplementary customs document formality but can also be applied to secure the transaction value of imported goods, so that state revenue can also be maintained.

Provisions regarding insurance in Indonesia is according to the Wetboek van Koopahandel Commercial Law (KUHD) are as follows:

a. KUHD Book I Chapter IX from Article 246 to 286 concerning insurance in general

b. KUHD Book II Chapter IX starting from Article 592 to 685 which regulates insurance for sea transportation, both concerning ship insurance and the transportation carried by sea.

c. Shipping Law No.21 / 1992 article 86 concerning the responsibilities of the carrier

In addition, insurance is also regulated in Act Number 40 of 2014 concerning Insurance. Under the provisions of Article 1 of this law, Insurance is an agreement between two parties, namely the insurance company and the policy holder, which is the basis for receiving premiums by the insurance company as an imbalance to:

a. Transfer to the insured or policyholder due to loss, damage, costs incurred, loss, or legal liability to the party that may be suffered by the insured or policy holder because it involves some events that may not be; or 
b. Payments based on the death of payments based on the payment of the insured have been determined and / or based on the results of savings funds

Based on the two definitions above, some insurance activities are as follows:

a. There are parties (ie), namely the guarantor (insurance company and the insured (policy holder);

b. There is an agreement;

c. There are risks or uncertain events (evenemen);

d. Rights and obligations of parties

This paper aims to review how the business process of issuing insurance for imported goods and how the results of the analysis of insurance data can be used as an alternative test tool for the value of imported transactions.

\section{RESEARCH METHODS}

\subsection{Research Approaches and Methods}

Choosing the right research methods are an essential part of the thesis work. The authors uses a qualitative approach, in order to obtain an overall picture of the insurance document research process and how to make it better.

\subsection{Data Collection Technique}

This data collection uses three methods, namely observation, interview, and literature study.

\section{Direct observation.}

"Some forms of observation that can be used in qualitative research, i.e. Participant observation, unstructured observation and unstructured group observation (Bungin, 2007)".

In this study the authors observed directly, so they can obtain the necessary data in accordance with the conditions in the field.

\section{Interview}

The interview is one of the techniques of gathering information from respondents, with the interview guidelines provided. This interview was aimed at Customs Specialists at Tanjung Priok Customs Office.

"Interviews have the power in their ability to target and focus directly on topic case studies as well as in their insights in delivering perceived causation and explanation conclusions (Yin, 2003)".

Meanwhile, according to Thomas (2011) "They give a 'rich picture' of this business, seen in it interpretive light, and in fact the person interviewed will determine the direction of the Interview".

\section{Literature Study}

This technique is exercised by reading literatures, and obtaining information related directly or indirectly to the discussed problems. This is intended to compare theories and 
practices related to insurance and customs value obtained through interview. After completion of the data collection process, the results of the interview will be analyzed. If in this analysis additional clarification is required, additional interviews will be needed. This is useful for improving data validity.

\subsection{Research Scope}

a. Geographic Scope.

For this study, the geographical scope is the Tanjung Priok Customs Office.

b. Scope of Time

The study is using the information collected from in-depth interviews conducted during the period 8 to 18 November 2019.

c. Scope of Respondents

This study took respondents from the Customs Specialists (PFPD) and the importers.

\subsection{Research Purposes}

a. To know the insurance business process for imported goods

b. To analyze the factors that PFPD consider in insurance data analysis

c. To test whether the results of insurance data analysis can be used as an alternative in the fairness test

d. To provide input to the resolution of the constraints that occurs.

\section{ANALYSIS AND DISCUSSION}

\subsection{Insurance Business Process for Imported Goods}

Insurance is a method for parties who want protection from various forms of danger, by contributing to a joint fund that is organized by the insurance company to provide compensation payments that may occur. Insurance is also defined as a relationship that occurs under a contract, if a party (insurance company) for the purpose of getting a premium, promises to provide compensation to other parties (buyers of insurance services) for losses that may occur in certain fields (Suyono, 2007)

Some terms that we must understand related to the insurance business process include: insurance policies, types of insurance and insurance premiums. Insurance certificate or policy is a written contract between the insurance company and a guaranteed party (the insured) that contains the terms and conditions of the agreement. The details of the insurance certificate, which must be filled usually are (India National Institute of Open Schooling, 2019):

a. Name of the shipper or consignor (the insured).

b. Full description of goods to be insured: The nature of the commodity to be insured is important for rating and underwriting. Different types of commodities are susceptible for different types of damage during transit- sugar, cement, etc. are easily damaged by 
seawater; cotton is liable to catch fire; liquid cargoes are susceptible to the risk of leakage and crockery, glassware to breakage; electronic items are exposed on the risk of theft, and so on.

c. Method and type of packing: The possibility of loss or damage depends on this factor. Generally, goods are packed in bales or bags, cases or bundles, crates, drums or barrels, loose packing, paper or cardboard cartons, or in bulk etc.

d. Voyage and Mode of Transit: Information will be required on the following points :

1) The name of the place from where transit will commence and the name of the place where it is to terminate.

2) Mode of conveyance to be used in transporting goods, (i.e.) whether by rail, lorry, air, etc., or a combination of two or more of these. The name of the vessel is to be given when an overseas voyage is involved. In land transit by rail, lorry or air, the number of theconsignment note and the date thereof should befurnished. The postal receipt number and date thereofis required in case of goods sent by registered post.

3) If a voyage is likely to involve a trans-shipment it enhances the risk. This fact should be informed while seeking insurance. Trans-shipment means the change of carrier during the voyage.

e. Risk Cover required: The risks against which insurance cover is required should be stated.

Marine insurance is one of the earliest forms of insurance. The most commonly used insurance coverage policy is the Lloyd policy from the UK, where the insurers unite in an association called the Institute of Marine Underwriters (asean.org, 2015). The Standard Clause issued by the Marine Underwriters Institute in London consists of:

a. Institute Cargo Clause for goods coverage.

b. Institute Time Clause for ship coverage.

Furthermore, in the world of shipping, there are two types of insurance, namely ship frame insurance and cargo insurance. Cargo insurance is divided into two, namely Marine Cargo Insurance and Carrier's Liability Insurance (Eun Sup Lee, 2002);

\section{a. Marine Cargo Insurance}

Insurance that is covered by the owner of the goods for possible loss caused by damage or loss of goods during the voyage.

b. Carrier's Liability Insurance

Insurance covered by the carrier for possible losses caused by claims from the owner of the goods due to damage or loss of goods.

Finally, insurance premiums are contributions in the form of money paid at a certain time by the insured to the insuring insurance company. In transportation by sea or in marine cargo insurance, some of the premium or premium is paid in advance to the insurance company. Insurance companies must be able to know in advance the benefits to be obtained so that accuracy is needed to calculate the amount of insurance premiums that must be received. 
The insured value of cargo marine insurance is not limited to the price of goods (invoice value) but can include (msig, 2019):

a. price of goods (invoice value),

b. costs (incidental charges) such as packing costs, land transportation, sea transportation (freight),

c. margins of $10 \%$ for

1) administrative costs,

2) additional costs, for example if they have to re-order because the cargo is damaged or lost

3) profit margin if goods are sold at their destination (profit margin),

d. taxes and import duties (import duties, taxes, etc.).

Therefore it will be very important to calculate an adequate Coverage Price for the insurance company so that in the event of the claim the insured gets sufficient compensation. The insured also needs to submit to the Insurer (insurance company) the calculation of the price of the coverage so that disputes do not occur in the event of a claim.

In appraising insured goods, insurance companies also have minimum limit value to analyze the fair value of the goods. These companies also have the ability to reject the value when certain criteria are fulfilled. Such criteria includes, but not limited to, (1) importers only bought insurance without clearly stated responsibility substance and (2) the minimum insurance value is not under the fair value of the insured goods value, either at market price valuation or internet-assisted valuation.

Freight insurance premiums are calculated as follows (tokio marine nichido, 2019):

a. Value of coverage $x$ Rate

b. Factors that influence the value of premiums include:

1) Type of goods / Cargo: general cargo, machinery, and others

2) Packing type: Container or Non-container

3) Ship Type: Steel, Barge, and others

4) Shipping routes: domestic or worldwide

5) Collateral Type: Clause A, B or C (Guarantee One Two or Three)

\subsection{Critical Factors in Insurance Data Analysis}

Based on the Director General of Customs and Excise Regulation Number PER-02 / BC / 2005 dated 16 February 2005 concerning Acceptable Insurance for Safeguarding International Trade Transactions as a Component of Customs Value for Calculation of Import Duties, there are types of insurance that can be accepted for securing trade transactions international as a component of customs value for import duty calculation, namely:

a. Individual Policy (closed), where the insurance policy for the carriage of goods is closed for each shipment of goods, and the amount of policy is negotiated between the guarantor and the insured for each shipment of goods; 
b. Open / Floating Policy, where the contract policy in the insurance of transportation of goods will be carried out in several shipments in accordance with what was agreed between the guarantor and the insured;

c. Open Cover Policy, where the contract policy in insurance will be carried out within a certain period, for example for 3 months, 6 months and so on in accordance with the agreement between the guarantor and the insured.

Based on the results of interviews with PFPD respondents, the examination of documents by PFPD related to insurance policies so far is generally only related to whether:

a. The insurance policy been attached if the incoterm does not contain insurance, for example "FOB / Ex work" on the invoice;

b. Is the issuance date of the insurance policy appropriate that is no later than the date of issuance of B / L (in individual policies);

c. Has the insurance premium cost been added to the transaction value (in the case of an insurance policy issued by an overseas insurance company);

Issuance of correction note by PFPD that is adding insurance cost as much as $0.5 \%$ of CFR is generally only related to:

a. Insurance costs have not been added to the transaction value (policies issued by foreign insurance companies);

b. The date of issuance of the insurance policy (in terms of individual policies) exceeds the date of issuance of the $\mathrm{B} / \mathrm{L}$;

In accordance with Regulation of the Director General of Customs and Excise Number PER-02 / BC / 2005 dated 16 February 2005 concerning Acceptable Insurance for Safeguarding International Trade Transactions as a Component of Customs Value for Import Duty Calculation, there are still a few things that are still rarely tested by PFPD related to issuance Import goods insurance including:

In the case of an insurance policy with an Open / Floating Policy type, it can be accepted as a component of customs value for the calculation of import duties if it meets the following test criteria:

(1) Whether issued by an insurance company or underwriter;

(2) Has the total amount of the sum insured been stated for several deliveries, and the maximum sum insured for each delivery;

(3) Does the validity period of the Open policy end after all goods mentioned in the policy have been sent without questioning how long the delivery of all goods lasts;

(4) Whether each time the goods shipment has been issued an Insurance Certificate.

In the case of an insurance policy with an Open Cover Policy type, it can be accepted as a component of customs value for the calculation of import duties if it meets the following test criteria:

(1) Whether issued by an insurance company or underwriter; 
(2) Has the mentioned policy period been valid (hours, months, years), also stated the maximum coverage price for each delivery;

(3) Does the validity period of the Open Cover Policy expire after the validity period of the policy expires without questioning how much all the coverage costs of shipping goods;

(4) Whether each time the goods shipment has been issued an Insurance Certificate.

The value of insured goods (amount insured), is in accordance between those listed on the insurance policy with the transaction value of imported goods listed on the invoice and import declaration or Pemberitahuan Impor Barang (PIB). In this case the value of insured goods (amount insured) according to the business insurance process ranges from $110 \%$ to $120 \%$ of the transaction value of imported goods. According to the interview results the value of insured goods is in accordance FOB (100\% FOB), according to CNF (100\% CNF) or a maximum of $110 \%$ of FOB/ CNF (Susanto, personal communication, 9 November 2019)

Associated with testing the value of insured goods (amount insured), interview respondents argued that under insurance law should be insured value equal to the value of goods / price of goods. Therefore, when interview respondents find an insurance value that exceeds the invoice value without a record of the percentage of the tolerance value, the value should be the value of the goods because the insurance company has an interest in the value of insurance premiums based on the value of goods that should be or at a reasonable minimum price (Ning Setyawati, personal communication, 8 November 2019).

For example, Importer A imports goods in the form of a Land Rover luxury car which actual price is USD 100,000.00 (one hundred thousand dollars), then the insurance company should be able to refuse the submission of the insured value of goods as a basis of coverage and premium payment with the value of the goods notified by the importer only in the amount of USD 50,000.00. Because insurance companies make a thorough assessment and consider a lot of information both in market prices and the benefits they get later from the value of premiums paid by importer A.

If the process of insurance policy issuance is conducted with a certain standards, the inappropriate practice of under invoicing in declaring goods value will be minimized. The appraisal process by insurance company will act as a filter in such issuance. Nonetheless, in many cases, the insurance company did not appraise the goods since some of them only issue policies for the comfort or formality of the importers without clear substances on the very essence of protection.

Based on the results of interviews with importers, it is known that there are some unscrupulous "insurance companies" who only sell insurance policy sheets as a supplementary customs document formality (according to the importer's order) without the substance of insurance services in the form of protection against risks or losses to be suffered;

\subsection{Problem in Insurance Examination}

Based on the interviews with PFPD, it is discovered that there are some obstacles found in examination process of insurance document as follows: 
- The validity of the insurance policy attached to the PIB is doubtful;

- The validity of the insurance policy of the issuing company (does not allow confirmation);

- PIB gets a green channel so documents are not required to be submitted unless there is a request (NPD);

- Insurance policies also do not always include insurance costs;

- The policy submitted is only the first page so that PFPD does not know the contents of the entire policy;

- The documents listed in the policy are different from the documents attached;

- The insured value is different from the invoice value but there is no record of the difference in the policy;

- The policy only states the value of the premium without mentioning when the premium is paid;

- The company name on the policy is different from the company name on the invoice

- the process of confirming the validity of the policy issuer to the insurance company takes time

- The insurance premium amount is almost entirely not included in the insurance certificate attached to the insurance, the insurance certificate only lists the insured value and the amount of the written premium as agreed

- For an open cover insurance policy, only an insurance certificate for each shipment is attached without attaching the parent insurance policy

Based on the results of interviews with PFPD respondents and based on case experience in examination of import documents related to insurance policies, the following matters were found:

a. PFPD respondent found that the insurance policy date exceeds the bill of lading date on import notification document. Importers attach individual policies that are opened on March 24, 2019, while the date on board at BL is March 23, 2019. Regulations of the DGCE No. P-02/2005 stated that individual policies can be accepted as customs value if the date specified in the individual policy does not exceed the date the goods were loaded on the departure ship. Another respondent also found similar case. It is the most common case in insurance examination

b. In another case, it is found that importers do not attach insurance policies, allegedly because they do not want to know what the actual value is and prefer to be charged an additional $0.5 \%$ rather than taking care of an insurance policy. For importers in accordance with PER-02 / BC / 2005 if they do not attach an insurance policy, then the added insurance value is only $0.5 \%$ of the CFR to be the customs value calculation.

c. Some cases, there is a double insurance policy, where in addition to an insurance policy issued by an overseas insurance company that states the actual insured value, there is also a domestic insurance policy that is only used as a supplementary customs document with a formal value, far below the previous insurance.

d. According a respondent, there is a notification that the value of the insured goods is higher than the value of the insured (amount insured) which is usually a maximum of 
$120 \%$ of the invoice price, and after an in-depth study found that the importer has under invoiced the imported goods that were notified

The price of goods listed in the insurance policy can not be used as the only reference to determine transaction value, but the issuance of an insurance policy in accordance with business processes should be used as instruments to minimize under invoicing practices.

An example can be seen from the issuance of Surveyor Reports (L / S) that contain types of goods and tariff items, even though the tariff posts listed are not necessarily completely correct, but the PFPD can make it as information in viewing the quantity and type of goods, and determining the classification of imported goods. Likewise through an insurance policy, it is hoped that PFPD will obtain preliminary information regarding the transaction prices of imported goods that are notified.

The fairness test based on Annex III PMK 160 of 2010 can be reached through 2 mechanisms. The first is research on matters related to sales, and the second compares the prices of goods with test values. And in the PMK it has been limited what is meant by test value is the transaction value of identical goods within a period of 30 days before / after the date of BL (such as the application of method II) or with methods IV and V. Insurance policies can be used as one of the tools in research matters relating to sales, where the research covers all aspects of the transaction / importation, one of which is an insurance policy (Wahyu Anggara, personal communication, 9 November 2019)

The insurance policy can be used as a tool to abort the transaction value when the insured value exceeds the invoice value without mentioning the percentage of the tolerance value. (Ning Setyawati, personal communication, 8 November 2019)

Cindhe Marjuang, said that the insured value listed in the Insurance Policy is not appropriate as an alternative to the reasonableness test, because the insured value is not limited to the value of goods only, but may include packing, transportation, import tax, margins, administrative costs, additional costs for example because damaged cargo requires reorder, etc., according to the agreement between the two parties (personal communication, November 8, 2019)

\section{CONCLUSION}

Based on the above explanation the authors conclude that although the insured value listed in the Insurance Policy is not appropriate as an alternative to be the reasonableness test, the role of insurance can be reinforced to minimize the practice of under invoicing.

To reinforce the role of insurance, the authors propose the following recommendation:

a. The insurance policy should be attached in the form of hardcopy in the original form, not photocopies or soft copies (in the case of an online document) because authenticity is needed to make it easier for document examiners to conduct document research;

b. Encouraging the use of insurance of imported goods as a matter of necessity for import trade transactions either through internal or external regulations. This not only has a positive impact on the role of insurance as a security of the value of trade transactions, but also can encourage the growth of the imported goods insurance industry in Indonesia; 
c. Collaborating with the Financial Services Authority (OJK) to curb "naughty" insurance companies by reporting on the discovery of insured value practices that are clearly very low when compared to the actual price of imported goods.

d. There is a need for education and supervision / audits of insurance companies in order to improve the validity of insurance policies

e. In order to make revisions to Article 6 point 3 of the Director General of Customs and Excise Regulation which reads: "in terms of the terminology of the delivery of imported goods is Cost Insurance Freight (CIF) Importers are not required to attach insurance policies at the time of submission of hardcopy of PIB." According to the authors the importer should still attach insurance policy because we can find out:

- Whether it is true that imported goods have been insured;

- The value of the insured item;

- The period insurance policy was issued.

\section{REFERENCES}

Anwar, Bilawal Alhariri. (2014). Tinjauan Yuridis Pelaksanaan Asuransi Kargo Maritim (Marine Cargo Insurance) Pada PT. Jasarahrdja Putera Insurance Cabang Surabaya. Retrieved from http://www.ugm.ac.id

ASEAN. (2015). Risks Management (including International Conventions): Marine Cargo Insurance. Chapter 3. Retrieved from http://www.asean.org

Bungin, Burhan (2007). Penelitian Kualitatif: Komunikasi, Ekonomi, Kebijakan Publik dan Ilmu Sosial lainnya. Jakarta: Putra Grafika

India National Institute of Open Schooling. (2019). Diploma in Insurance Services: Marine Insurance Module. Retrieved from http://www.nios.ac.in

Lee, Eun Sup. (2002). The Changing Liability System of Sea Carriers and Maritime Insurance: Focusing on the Enforcement of the Hamburg Rules, 15 Transnational Lawyer 241, page 5

MSIG. (2019). Marine Claim case sharing: Mark-up value for cargo shipment. Retrieved from http://www.msig.com.hk

Rani, M.J.J.S. (2016). Asuransi Tanggung Gugat Kapal Terhadap Risiko dan Evenemen Dalam Kegiatan Pelayaran Perdagangan Melalui Jalur Laut. Jakarta

Simanjuntak, Pangaribuan. (1980). Hukum Pertanggungan dan Perkembangannya. Jakarta: BPHN

Sugiyono (2010). Metode Penelitian Pendidikan Pendekatan Kuantitatif, kualitatif, dan R\&D. Bandung: Alfabeta

Suyono, R., (2007). Shipping: pengangkutan intermodal ekspor impor melalui laut. Jakarta: PPM.

Tokio Marine Nichido. (2019, Jul). Outline of Ocean Marine Cargo Insurance. Retrieved from http://www.jrs.tokyo

World Trade Organization (1994). Agreement on Implementation of Article VII of the General Agreement on Tariffs and Trade 1994. Retrieved from http://www. . WTO.org

Yin, R.K. 2003. Case study research. Design and methods. Thousand Oaks, Calif.: Sage. 3. painos. 